\title{
Steroid 21-Monooxygenase Deficiency
}

National Cancer Institute

\section{Source}

National Cancer Institute. Steroid 21-Monooxygenase Deficiency. NCI Thesaurus. Code C101042.

Less than necessary amount of the enzyme steroid 21-monooxygenase; which is necessary to synthesize cortisol. 